Jurnal Penelitian dan Karya Ilmiah

\title{
PENGARUH PEMBELAJARAN INKUIRI TERBIMBING TERHADAP KEMAMPUAN PENALARAN DAN KOMUNIKASI MATEMATIS SISWA
}

\author{
${ }^{1}$ Agus Soleh Riyadi, ${ }^{2}$ Jarnawi Afgani Dahlan, ${ }^{3}$ Tita Rosita \\ 1 Program Pascasarjana Universitas Terbuka \\ ${ }^{2}$ Universitas Pendidikan Indonesia \\ Email: agusoleh.riyadi@gmail.com
}

\begin{abstract}
Abstrak
Tujuan penelitian ini adalah untuk menganalisis perbedaan kemampuan penalaran dan komunikasi matematis antara siswa yang mendapat pembelajaran inkuiri terbimbing dengan siswa yang mendapat pembelajaran konvensional. Penelitian ini menggunakan metode kuasi eksperimen dengan desain pretest and postest non-equivalent group design yang dilaksanakan di SMPN 1 Bangodua kelas VIII. Penelitian ini menggunakan instrumen tes yang mengukur kemampuan penalaran dan komunikasi matematis siswa. Berdasarkan hasil penelitian diperoleh: (1) Terdapat perbedaan kemampuan penalaran matematis antara siswa yang mendapat pembelajaran inkuiri terbimbing dengan siswa yang mendapat pembelajaran konvensional. Kemampuan penalaran matematis siswa yang mendapat pembelajaran inkuiri terbimbing lebih tinggi dari siswa yang mendapat pembelajaran konvensional. (2) Terdapat perbedaan kemampuan komuniksasi matematis antara siswa yang mendapat pembelajaran inkuiri terbimbing dengan siswa yang mendapat pembelajaran konvensional. Kemampuan komunikasi matematis siswa yang mendapat pembelajaran inkuiri terbimbing lebih tinggi dari siswa yang mendapat pembelajaran konvensional.
\end{abstract}

Kata kunci: inkuiri terbimbing, penalaran matematis, komunikasi matematis 


\begin{abstract}
The purpose of this study was to analyze differences in reasoning ability and mathematical communication between students who received guided inquiry learning with students who received conventional learning. This research uses quasi experimental method with pretest and postest design non-equivalent group design which is implemented in SMPN 1 Bangodua in class VIII. This study uses a test instrument that measures students' reasoning and mathematical communication skills. Based on the research results obtained: (1) There is a difference in the ability of mathematical reasoning between students who received guided inquiry learning with students who received conventional learning. The mathematical reasoning abilities of students who receive guided inquiry learning are higher than students receiving conventional learning. (2) There is a difference in the ability of mathematical communication between students who received guided inquiry learning with students who received conventional learning. The ability of mathematical communication of students who receive guided inquiry learning is higher than students who received conventional learning.
\end{abstract}

Keywords: guided inquiry, mathematical reasoning, mathematical communication 


\section{Pendahuluan}

Matematika merupakan salah satu bidang ilmu yang sangat penting bagi siswa dan turut berperan dalam mencerdaskan kehidupan bangsa. Sebagaimana yang dikemukakan oleh Russefendi (2014) bahwa matematika berguna bagi bekal siswa dalam kehidupan sehari-hari, untuk studi lanjut, sebagai pengetahuan, dan kemampuan prasyarat. Selain itu, matematika juga berperan untuk mengembangkan suatu ilmu dan mencerdaskan bangsa atau manusia. Pernyataan tersebut menunjukkan bahwa peran matematika yang sangat penting bagi siswa, sehingga siswa perlu untuk dapat menguasainya.

Kompetensi matematika yang diperlukan siswa secara umum termuat dalam standar proses pembelajaran matematika. Standar proses menurut National Council of Teacher of Mathematics (NCTM, 2000) yaitu: pemecahan masalah, penalaran dan bukti, komunikasi, koneksi, dan representasi. Standar proses tersebut sejalan dengan tujuan pembelajaran matematika yang tercantum dalam Peraturan Menteri Pendidikan Nasional Nomor 22 Tahun 2006, yang secara garis besar menyebutkan sebagai berikut: (1) pemahaman konsep; (2) penalaran; (3) pemecahan masalah; (4) mengkomunikasikan ide dan gagasan; dan (5) sikap menghargai kegunaan matematika. Dengan demikian, siswa perlu memenuhi standar proses pembelajaran nmatematika tersebut untuk dapat menguasai materi pelajaran matematika.

Berdasarkan uraian tersebut, diketahui bahwa penalaran matematis merupakan salah satu kemampuan yang penting untuk dapat dikuasai oleh siswa. Sebagaimana rekomendasi hasil penelitian Sumarmo (dalam Afgani, 2014) mengenai pentingnya proses penalaran dalam belajar matematika, yakni guru hendaknya mengusahakan agar siswa terampil mengaplikasikan konsep atau rumus, lebih dari itu siswa lebih didorong ke arah pencapaian tingkat penalaran yang lebih tinggi.

Kemampuan penalaran siswa juga erat kaitannya dengan kemampuan komunikasi matematis. Seperti pada penjelasan Brodie (2010) yang mengungkapkan bahwa dalam penalaran matematis meliputi peranan penting diantaranya yaitu intuisi, 
kreativitas, imajinasi, penjelasan dan komunikasi. Demikian pula penjelasan yang dikemukakan oleh NCTM (2000) komunikasi merupakan bagian yang penting dalam pembelajaran matematika. Dalam proses belajar tersebut, kemampuan komunikasi matematis dapat membantu siswa membangun konsep pemahaman, dan siswa dapat menganalisis masalah matematika. Dalam hal ini siswa tertantang untuk berpikir menyelesaikan persoalan matematika dan mengkomunikasikan hasil pemikiran tersebut kepada teman sekolah atau orang lain baik secara lisan maupun dalam tulisan.

Uraian di atas menjelaskan pentingnya siswa untuk dapat memiliki kemampuan penalaran dan komunikasi matematis. Namun di sisi lain, kedua kemampuan tersebut masih ditemukan berbagai masalah. Data menunjukkan bahwa kemampuan penalaran matematis di Indonesia masih rendah. Berdasarkan data dari TIMSS (Trends in International Mathematic and Science Study) pada tahun 2011 yang menunjukkan kemampuan ratarata siswa Indonesia pada tiap domain masih berada dibawah rata-rata internasional. Pada domain kognitif level penalaran (reasoning), rata-rata persentasenya yaitu 17\%, merupakan paling rendah dari rata-rata International sebanyak 30\%. Angka tersebut menunjukkan bahwa Indonesia masih tertinggal dari negaranegara anggota ASEAN seperti Thailand, Singapura, dan Malaysia.

Selain itu, hasil Programme International Student Assesment (PISA) pada kelas VIII juga menunjukkan bahwa untuk kemampuan analisis, penalaran dan komunikasi matematis di Indonesia masih tergolong rendah. Hal tersebut ditunjukkan oleh kemampuan literasi matematika yang rendah di Indonesia. Data hasil PISA pada tahun 2012 tersebut menjelaskan bahwa Indonesia masih memiliki peringkat 10 besar terbawah dari keseluruhan 65 negara yang turut berpartisipasi (OECD, 2014).

Berdasarkan uraian di atas, terlihat bahwa pembelajaran matematika di Indonesia khususnya belum mampu mengembangkan kemampuan penalaran dan komunikasi matematis siswa. Diperlukan upaya untuk meningkatkan 
kemampuan penalaran dan komunikasi matematis siswa. Salah satu upaya untuk dapat meningkatkan kemampuan tersebut adalah dengan pembelajaran yang inovatif, yang dapat membimbing siswa untuk berpartisipasi aktif, memberikan kesempatan bagi siswa untuk berpikir dalam menyelesaikan berbagai permasalahan matematis.

Salah satu pembelajaran yang mampu memenuhi ciri-ciri di atas adalah pembelajaran inkuiri. Hal tersebut didasari oleh pendapat yang dikemukakan oleh Sanjaya (dalam Sutawidjaja dan Afgani, 2015) yang menyatakan beberapa ciri utama pembelajaran inkuiri yaitu penekanan pada aktivitas siswa secara optimal untuk mencari dan menemukan. Lebih lanjut, pembelajaran inkuiri juga mengarahkan siswa untuk mencari dan menemukan sendiri pada suatu masalah sehingga diharapkan siswa dapat menumbuhkan sikap percaya dirinya.

Pembelajaran inkuiri memiliki beberapa keunggulan dibandingkan dengan pembelajaran konvensional. Menurut Sutawidjaja dan Afgani (2015) mengungkapkan beberapa keunggulan pembelajaran inkuiri diantaranya yaitu (1) siswa dapat mengembangkan konsep dasar dan ide-ide yang lebih baik; (2) siswa termotivasi untuk berpikir dan berusaha atas inisiatif pribadi, objektif, dan terbuka; (3) siswa termotivasi untuk berpikir intuitif dan dapat merumuskan hipotesisnya sendiri; (4) siswa diberi kebebasan untuk belajar mandiri. Dari uraian tersebut, pembelajaran inkuiri terbimbing diduga mampu meningkatkan kemampuan penalaran dan komunikasi matematis siswa.

\section{Tujuan Penelitian}

1) Menganalisis perbedaan kemampuan penalaran matematis antara siswa yang mendapat pembelajaran inkuiri terbimbing dengan siswa yang mendapat pembelajaran konvensional.

2) Menganalisis perbedaan kemampuan komuniksasi matematis antara siswa yang mendapat pembelajaran 
inkuiri terbimbing dengan siswa yang mendapat pembelajaran konvensional.

\section{Metode}

Metode yang digunakan pada penelitian ini adalah metode kuasi eksperimen dengan desain pretest and postest non-equivalent group design, dengan tujuan melihat hubungan sebab akibat melalui pemanipulasian yang dilakukan terhadap variabel bebas dan menguji perubahan yang diakibatkan oleh pemanipulasian tersebut. Terdapat dua kelompok yaitu kelompok eksperimen dan kelompok kontrol yang akan dibandingkan secara natural dan tidak dilakukan pemilihan secara acak seperti halnya pada penelitian yang sebenarnya.

Tabel 1 Desain Penelitian

\begin{tabular}{ccc}
\hline Pretes & Treatment & Postes \\
\hline $\mathrm{O}_{1}$ & $\mathrm{X}$ & $\mathrm{O}_{2}$ \\
$\mathrm{O}_{1}$ & & $\mathrm{O}_{2}$ \\
\hline
\end{tabular}

Keterangan:

$\mathrm{O}_{1}$ : Skor kemampuan penalaran dan komunikasi matematis siswa sebelum perlakuan (pretes)

$\mathrm{O}_{2}$ : Skor kemampuan penalaran dan komunikasi matematis siswa sesudah perlakuan (postes)

$\mathrm{X}$ : Penerapan pembelajaran inkuiri terbimbing

Penelitian ini dilaksanakan di SMPN 1 Bangodua Kabupaten Indramayu. Data dalam penelitian ini menggunakan instrumen tes kemampuan penalaran dan komunikasi matematis. Sebelum digunakan dalam penelitian, soal tes terlebih dahulu diujicobakan kepada kelas non sampel dengan tujuan mengetahui validitas, reliabilitas, daya pembeda, dan indeks kesukaran soal tersebut.

Data yang akan diolah adalah data pretes, postes dan N-gain dari hasil tes penalaran dan komunikasi matematis siswa. Analisis terdiri dari dua bagian, statistika deskriptif dan statistika 
inferensial. Tujuan analisis deskriptif yaitu untuk melihat gambaran umum pencapaian kemampuan penalaran dan kemampuan komunikasi matematis yang terdiri dari rataan, skor maksimum, skor minimum, dan skor maksimum ideal. Analisis statistika inferensial adalah proses pengambilan kesimpulankesimpulan berdasarkan data sampel yang lebih sedikit menjadi kesimpulan yang lebih umum untuk sebuah populasi.

\section{Hasil dan Pembahasan}

Berikut ini akan dijelaskan hasil dan pembahasan yang meliputi variabel-variabel yang diteliti, yaitu pembelajaran inkuiri terbimbing, kemampuan penalaran matematis dan kemampuan komunikasi matematis siswa.

\section{Pembelajaran Inkuiri Terbimbing}

Hasil penelitian menunjukkan bahwa pembelajaran inkuiri terbimbing berpengaruh terhadap kemampuan penalaran dan komunikasi matematis siswa. Siswa yang mendapat pembelajaran inkuiri terbimbing memiliki pencapaian dan peningkatan kemampuan penalaran dan komunikasi matematis siswa yang lebih tinggi dibandingkan dengan siswa yang mendapat pembelajaran konvensional.

Hasil pencapaian dan peningkatan kemampuan penalaran dan komunikasi matematis siswa tersebut berkaitan erat dengan proses pembelajaran yang menuntut siswa aktif dalam belajar. Pembelajaran inkuiri terbimbing merupakan pembelajaran yang memberikan kesempatan kepada siswa untuk aktif berlatih dan membiasakan dengan permasalahan. Selain itu, siswa diberikan keleluasaan untuk menanamkan dasar-dasar berpikir ilmiah dan mengkomunikasikan pemikirannya sehingga dalam proses pembelajaran ini siswa lebih banyak berpusat pada siswa. Siswa benar-benar ditempatkan sebagai subjek yang belajar. Langkahlangkah pembelajaran inkuiri terbimbing yang digunakan mengacu pendapat Sanjaya seperti yang diungkapkan Afgani (2015), meliputi: 1) orientasi; 2) merumuskan masalah; 3) merumuskan hipotesis; 4) mengumpulkan data; 5) menguji hipotesis; dan 6) merumuskan kesimpulan. 


\section{Kemampuan Penalaran Matematis}

Pada tahap awal penelitian, siswa diberikan pretes untuk mengetahui kemampuan awal penalaran dan komunikasi matematisnya. Berdasarkan hasil pengolahan data pretes, dengan skor ideal maksimal 30, diperoleh bahwa rata-rata pretes kelompok eksperimen adalah 10,75 sedangkan untuk kelas kontrol memiliki rata-rata 10,88. Kelas eksperimen memiliki nilai minimum 2 dan nilai maksimum 20. Sedangkan kelompok kontrol nilai minimum 0 dan nilai maksimum 10. Hasil ini menunjukkan perolehan rata-rata nilai pretes kedua kelompok tidak jauh berbeda.

Untuk mengetahui apakah perbedaan kemampuan kedua kelompok tersebut signifikan atau tidak, maka dilakukan uji statistik dengan melihat perbedaan rata-rata kedua kelompok. Uji beda yang digunakan menggunakan uji-t jika kedua data berdistribusi normal dan homogen, meggunakan uji-t' jika kedua data hanya berdistribusi normal tetapi tidak homogen, dan menggunakan uji Mann Whitney jika kedua data tidak berdistribusi normal. Hasil uji prasyarat menunjukkan bahwa baik data pretes maupun postes memiliki data yang berdistribusi normal dan homogen, sehingga menggunakan uji-t (independent samples t-test).

Hasil pengujian statistik independent samples t-test untuk skor pretes kemampuan penalaran matematis menunjukkan nilai Sig.(2-arah) sebesar 0,922 lebih dari taraf signifikansi sebesar 0,05. Hal tersebut menggambarkan bahwa tidak terdapat perbedaan rata-rata skor pretes kemampuan penalaran matematis antara kelompok eksperimen dan kelompok kontrol. Sehingga, untuk mengetahui pengaruh pembelajaran inkuiri terbimbing dapat dilihat dari hasil postes, sedangkan untuk melihat peningkatan kemampuannya menggunakan skor N-gain.

Kemudian siswa kelompok eksperimen dan kelompok kontrol diberikan perlakuan, masing-masing yaitu dengan pembelajaran inkuiri terbimbing dan pembelajaran konvensional. Masing masing kelas diberikan materi yang sama yaitu materi phytagoras. Proses pembelajaran dilakukan 4 pertemuan. Setelah 
proses pembelajaran selesai kemudian siswa diberikan postes untuk mengetahui kemampuan penalaran dan komunikasi matematis siswa setelah pembelajaran.

Hasil pengolahan data postes diperoleh bahwa rata-rata postes kelompok eksperimen adalah 17,84 sedangkan untuk kelompok kontrol 14,50. Kelas eksperimen memiliki nilai minimum 6 dan nilai maksimum 28 dari skor maksimal ideal 30. Sedangkan kelompok kontrol memiliki nilai minimum 2 dan nilai maksimum 28.

Lebih lanjut, hasil uji t menunjukkan bahwa rata-rata postes antara kelompok kontrol dan eksperimen memiliki perbedaan yang signifikan. Hal tersebut ditunjukkan oleh nilai Sig.(2-arah) sebesar 0,027 kurang dari taraf signifikansi sebesar 0,05. Berdasarkan hasil tersebut, dapat diartikan bahwa setelah pembelajaran, kemampuan penalaran matematis kelompok eksperimen lebih tinggi dibandingkan dengan kelompok kontrol.

Selain itu, rataan peningkatan kemampuan penalaran matematis siswa juga terdapat perbedaan yang signifikan. Hal tersebut ditunjukkan dari skor $\mathrm{N}$-gain pembelajaran inkuiri terbimbing lebih besar dibandingkan siswa dengan pembelajaran konvensional. Dimana skor N-gain kelompok eksperimen sebesar 0,40 termasuk kategori sedang, sedangkan kelompok pembelajaran konvensional 0,21 termasuk kategori rendah.

\section{Kemampuan Komunikasi Matematis}

Analisis deskriptif untuk kemampuan kemampuan komunikasi matematis yang meliputi pretes, postes, dan N-gain kelompok eksperimen dan kontrol. Hasil pretes menunjukkan kelompok eksperimen memiliki rata-rata 13,19 dari skor maksimal ideal 32, dengan skor minimal 2 dan skor maksimal 24. Sedangkan kelompok kontrol memiliki rata-rata 12,03 dengan skor minimal dan skor maksimal berturut-turut 1 dan 26 .

Data tersebut menunjukkan bahwa rata-rata skor pretes antara siswa kelompok eksperimen dan kelompok kontrol tidak jauh berbeda. Hal tersebut diperkuat oleh nilai uji-t yang menunjukkan nilai Sig.(2-arah) sebesar 0,404. Angka tersebut lebih dari taraf signifikansi sebesar 0,05. Sehingga dapat 
dikatakan bahwa tidak terdapat perbedaan antara kemampuan awal komunikasi matematis antara kelompok eksperimen dan kelompok kontrol.

Setelah dilakukan pembelajaran terhadap kelompok eksperimen dan kelompok kontrol, hasil pengujian statistik dengan independent samples t-test membuktikan bahwa kemampuan komunikasi matematis siswa yang mendapatkan pembelajaran inkuiri terbimbing dengan pembelajaran konvensional memiliki perbedaan yang signifikan. Hal tersebut ditunjukkan oleh nilai Sig.(2-arah) sebesar 0,020<0,05 (taraf signifikansi).

Pada aspek peningkatan kemampuan komunikasi matematis siswa juga terdapat perbedaan yang signifikan. Hal tersebut ditunjukkan oleh skor N-gain pembelajaran inkuiri terbimbing yang lebih besar dibandingkan siswa dengan pembelajaran konvensional. Skor N-gain kelompok eksperimen sebesar 0,39 termasuk kategori sedang, sedangkan kelompok pembelajaran konvensional memiliki skor dengan kategori rendah yaitu 0,20 .

\section{Kesimpulan dan Saran}

\section{A. Kesimpulan}

Secara umum, dari penelitian ini dapat disimpulkan bahwa pembelajaran inkuiri terbimbing berpengaruh secara signifikan terhadap kemampuan penalaran dan komunikasi matematis siswa. Penjelasannya sebagai berikut.

1. Kemampuan penalaran matematis siswa yang mendapat pembelajaran inkuiri terbimbing lebih tinggi dari siswa yang mendapat pembelajaran konvensional. Selain itu, peningkatan kemampuan penalaran siswa dengan pembelajaran inkuiri terbimbing sebesar 0,40 berada pada kategori sedang, peningkatan tersebut lebih tinggi daripada peningkatan kemampuan penalaran matematis siswa kelas pembelajaran konvensional sebesar 0,21 berada pada kategori rendah. 
2. Kemampuan komunikasi matematis siswa yang mendapat pembelajaran inkuiri terbimbing lebih tinggi dari siswa yang mendapat pembelajaran konvensional. Begitu juga dengan peningkatan kemampuan penalaran siswa dengan pembelajaran inkuiri terbimbing sebesar 0,39 berada pada kategori sedang, angka tersebut lebih tinggi dibandingkan dengan peningkatan kemampuan komunikasi matematis siswa dengan pembelajaran konvensional sebesar 0,20 berada pada kategori rendah.

\section{B. Saran}

1. Diharapkan pembelajaran ini dapat digunakan sebagai salah satu alternatif untuk meningkatkan kemampuan penalaran dan komunikasi matematis pada materi lainnya.

2. Guru harus memperhatikan pemilihan materi yang sesuai, mempersiapkan bahan ajar dan lembar kerja siswa untuk mendukung pelaksanaan pembelajaran, mempersiapkan soal-soal untuk kemampuan matematis sesuai dengan indikator yang akan dicapai, dan guru hendaknya memprediksi kondisi yang dihadapi siswa dalam setiap tahapan pembelajaran inkuiri terbimbing.

3. Pembelajaran inkuiri terbimbing patut diteliti untuk melihat pengaruhnya pada kemampuan matematis yang lain selain kemampuan penalaran dan komunikasi matematis.

\section{Referensi}

Afgani, J. D. (2014). Analisis kurikulum matematika. Banten: Universitas Terbuka.

Brodie, Karin. (2010). Teaching mathematical reasoning in secondary school classroom. New York City: Springer Science and Business Media.

Liandari, E., Siahaan, P., Kaniawati, I., Isnaini (2017). Upaya meningkatkan kemampuan merumuskan dan menguji hipotesis melalui pendekatan keterampilan proses sains 
dengan metode praktikum. Jurnal Wahana Pendidikan Fisika, Vol. 2 No.1, 50-55.

NCTM. (2000). Principles and standars for school mathematics. Reston, VA: NCTM.

OECD. (2014). PISA 2012 result: what students know and can dostudent performance in mathematics, reading and science (volume I) (Rev. ed.). Paris: OECD Publishing.

Ruseffendi, H. E. T. (2014). Perkembangan pendidikan matematika. Banten: Universitas Terbuka.

Sulistyono, Radiana, dan Fadillah (2014). Pengelolaan panel kontrol untuk memaksimalkan hasil belajar pelajaran produktif pada jurusan teknik listrik. Jurnal Pendidikan dan Pembelajaran. Vol 3, No 7

Sutawidjaja, A. dan Afgani, J. D. (2015). Pembelajaran matematika. Banten: Universitas Terbuka. 